\title{
There needs to be greater equality within Indonesia's diasporic communities if their strengths are to be properly realised
}

Edition 8, 2021

Annisa D. Amalia, Muhamad Arif, Arivia T.D Yuliestiana

DOI: 10.37839/MAR2652-550X8.16

Diasporic communities are increasingly being viewed by individual nation-states and global bodies as important for economic development, both for sending and receiving countries.

This trend is also being reflected in Indonesia and its diaspora. The term diaspora was not popularly known in Indonesia until the first Congress of Indonesian Diaspora (CID) was held in Los Angeles in 2012. At present, Indonesian diasporic communities in multiple countries are seeking ways to develop various means of engagement with the homeland.

It is difficult to estimate the total size of the Indonesian diaspora. Estimates of the size of diasporas are usually drawn from international datasets about the number of migrants by country of origin. The latest figures from the United Nations Department of Economic and Social Affairs indicate that there were 4.6 million migrants from Indonesia living abroad in mid-2020. The Indonesian Diaspora Network (IDN), a diaspora representative organisation that was formed following the 2012 CID and which has sponsored several subsequent CIDs, estimates the size of the Indonesian diaspora to be 8 million,comprising both Indonesians by 
birth/nationality and ancestry.

At present, Indonesia does not have a clear diaspora engagement strategy or policy, despite having active diasporic communities which have vast potential to enhance Indonesia's economic prosperity. Unfortunately, existing mechanisms of engagement with diaspora create and sustain a varying degree of inequality among their members. This needs to change if the potential of diasporic communities is to be fully utilised.

\section{Changing understanding of the term Indonesian 'diaspora'}

There have been relatively few studies on the Indonesian diaspora, although scholarly attention has grown in recent years. However, there remains a lack of agreement on how to define and categorise the Indonesian diaspora.

In 1993, noted political scientist Evelyn Tan-Cullamar was likely the first scholar to use the term 'Indonesian diaspora'. In her article 'The Indonesian Diaspora and Philippine-Indonesian Relations' she discusses the migration of people from the Sangire-Talaud region in Sulawesi to the Philippines since the Dutch colonial period in the 1800s and early 1900s.

Other studies explore the diasporic journey of people originating from a number of regions in Indonesia from an ethnic-based perspective. A notable example is work on the Javanese in Suriname by historians Rosemarijn Hoefte and Peter Meel. Buginese and Madurese communities in Sabah, Malaysia and Minang groups in the Netherlands have also permanently settled in destination countries and developed distinctive cultural practices which are different from the original practices in Indonesia.

Resonating with the early academic description of diaspora, other studies highlighting the ethnicity of Indonesian diaspora groups focus on migrant 
communities generated by conflict and separatist movements, such as the Moluccan, Acehnese, West Papuan, and East Timorese diasporas. The security discourse in the initial use of the term diaspora to denote the dispersion of exile communities-including but not limited to Jewish, Greek, and Armenian, and those who escaped civil wars following the end of the Cold War-was also adopted in these studies on the Indonesian diaspora.

These complex historical accounts, however, are largely absent from contemporary narratives on the Indonesian diaspora. This is partly because many ethnic-based migrant communities no longer associate themselves with Indonesia; not only because they have renounced their Indonesian nationality and dual citizenship is not allowed, but also because their migration occurred before Indonesia was proclaimed an independent state and nation.

As the term diaspora has 'travelled across time', the narratives on Indonesian diaspora have also evolved. Along with the rising number of diaspora institutions across the globe, the formation of IDN in 2012 marks the first Indonesian community group dedicated to Indonesian diaspora within nationalist and development-related discourses.

\section{Different modes of engagement with the homeland}

Indonesian diaspora groups have been involved in various transnational activities, both within and across receiving countries. The IDN, which has grown rapidly since its founding to be present in 26 countries $_{\llcorner}$has propelled these activities by facilitating regular interactions between its members.

The IDN's engagement with the homeland occurs primarily in three sectors: political, economic, and social. Over time, the IDN has developed a formal, organised structure: for instance, it has established 12 taskforces, one of which focuses on 
immigration and citizenship with a mandate to help diaspora realise the dual citizenship agenda.

Initially, the IDN focused on its overarching political aim of achieving the legal change required for Indonesia to permit dual citizenship. However, after the proposal was rejected by Indonesia's House of Representatives despite being included in the National Legislative Program (Prolegnas), 2015-2019, and also supported by President Joko Widodo, the IDN took a different approach, focusing more on the economic and social spheres.

Multiple economic programs were developed and institutionalised within the IDN. At the same time, a number of social projects, which were initially manifested in charity projects and cultural promotion, have also been transformed into more regularised, long-term programs. Illustrative examples include the IDN Brain Bank (a database of diasporic resources), the Indonesian Diaspora Business Council (a business representative organisation), the Indonesian Diaspora Foundation (IDF) (a charitable foundation that funds developmemnt projects), and a special taskforce for protection of migrant workers.

An interesting characteristic of IDN as the first formalised Indonesian diaspora group is that-in contrast with the rise of government-backed diaspora institutions in other nations-it was initiated by civil society. The group's proposal for dual citizenship, for example, was started by an online petition coordinated by 29 people across 18 countries. After the issue was formalised in the IDN's organisational structure, financial and social resources were mobilised to lobby the Indonesian government in formal (inviting Indonesian legislators to CID) and informal (personal network) ways.

Although the initial proposal to change Indonesian citizenship laws to allow dual citizenship was unsuccessful, the IDN continues to keep related issues on the government's policy agenda. For example, in 2016 special visa regulations for former Indonesian citizens and their families were allowed under Government 
Regulation No. 26, and in 2017 the Presidential Regulation No. 76 allowed for the issuance of 'diaspora cards' which are identification for Indonesians overseas and which provide certain economic rights, such as property ownership in Indonesia.

Since 2017, diasporic communities have been working on various long-term projects in collaboration with the government, such as integrated teaching technology in Papua in cooperation with the Ministry of National Development Planning (Bappenas); as well as the integrated boarding school program and telemedicine pilot project in health facilities (Puskesmas) in the same area in 2019. In 2020, various social projects were launched, including Diaspora Care which aims to support the families of Indonesian migrant workers who have been laid off due to the COVID-19 pandemic. Diaspora engagement strategies currently mainly focus on economic and social programs, but political goals are still being actively pursued. An example is reform of the electoral law to establish a special electoral district for the diaspora. This would mean that the diaspora would have dedicated elected representatives who would be expected to channel and facilitate the diaspora's aspirations to the government.

In implementing various strategies of engagement with the homeland, Indonesian diasporic communities cultivate symbolic and social ties to their relatives back home. For instance, the symbolic idea of being 'Indonesian' is socialised and reinforced through nationalist discourse by diasporic communities through various approaches. These include the 'obligatory' display of Indonesian culture or a traditional art performance at diasporic meetings and forums. Within the same communities, notions of shared interests and obligations attached to Indonesian identity-for instance, the idea that members of the diaspora should contribute positively to the homeland-serve as social ties which are continuously communicated and negotiated.

The CIDs have actively promoted these social and symbolic ties. This forum was established as a means of exchanging ideas among so-called Indonesian movers (diaspora members) and stayers (those who have remained at home), especially 
government policymakers, regarding various issues in the home country, but it has also served a more subjective purpose.

\section{From escaping poverty to new inequalities abroad}

Migration has been long perceived as a strategy to escape poor economic conditions in countries of origin, especially limited employment opportunities. The changing structure of the global economy is also an important determinant of mass labour migration from poor to wealthy economies. During the 1970s, the world saw a period of advanced industrialisation and shift to market-based economies in the Global North. However, these economies have also experienced a lack of workers in entrylevel manual areas such as domestic work and the fisheries and construction sectors, which are mostly filled by migrants from developing countries.

Indonesia is largely a 'sending' country for migrant workers. The economic development potential of those migrants is well recognised by the Indonesian government through its repeated phrase 'remittances heroes'. According to the International Organization for Migration (IOM), remittances sent by Indonesian migrant workers have contributed around one percent to the country's GDP each year, a figure which had been increasing before the COVID-19 pandemic during which thousands of Indonesian migrant workers lost their jobs. Lately, the significant economic contribution of the diaspora is also gaining more popularity, with the government's plan to issue 'diaspora bonds' in November 2020. This debt instrument aims to raise finance and widen the investor base in relation to Indonesian nationals living abroad, particularly in response to the economic shutdown caused by the pandemic.

However, the spaces where diasporic communities continue to connect with the homeland and contribute to its economic development also facilitate the creation of new inequalities. 
Among Indonesian diasporic communities, the notion of shared identity as Indonesian often serves as merely symbolic. If we look more closely, it becomes clear that the communities are differentiated along hierarchical class lines.

The Indonesian diasporic communities such as IDN have mainly been formed and organised by Indonesians working as 'professionals', often as citizens or permanent residents of their 'receiving' countries. Indonesian migrants working as manual labourers in various sectors under temporary visa schemes are largely missing from the representation of Indonesian diaspora.

Although IDN defines the Indonesian diaspora in broad terms, the representation of the diaspora is dominated by knowledge workers and elites. Several migrant workers we interviewed during our research did not feel as if they belonged to the diaspora group because most of the time they were only involved in symbolic, ceremonial events. Many IDN events showcasing the Indonesian diaspora's achievements and contributions also overlook those of manual workers.

Apart from the IDN, multiple communities for academics have also been formed, such as the Indonesian American Society of Academics and International Indonesian Scholar Society (Ikatan Ilmuwan Indonesia Internasional/I4). These communities have developed strong connections with their counterparts in Indonesia on the merits of dual citizenship for Indonesia. This work has included studies and seminars on the subject, the preparation of a Naskah Akademik (academic paper) to justify the proposed change to citizenship laws, and collaborative research projects between Indonesian academics in and outside Indonesia funded by the Indonesia Endowment Fund for Education.

Here, our understanding of the Indonesian diaspora and the associated transnational processes cannot be isolated from the wider global political-economic situation. As anthropologist Aihwa Ong warns, the use of a political-economic framework should balance claims that 'transnational mobility and its associated processes have great liberatory potential [...] for undermining all kinds of oppressive structures.' 
Labour power has been commodified which leads to an unequal valuation of certain types of work and the devaluation of the work of Indonesian migrants in 'low-paid' sectors. Furthermore, the temporary status attached to many Indonesian manual workers also adds to the othering process in diaspora interactions. As anthropologist Nicholas Van Hear argues, socio-economic privileges need to be examined in the context of the permanent-temporary divide between classes of migrants.

The varying forms of inequality within diasporic interactions could undermine the development potential of the Indonesian diaspora. Exclusion might present a threat to the unity of Indonesian overseas communities where labour groups who are discriminated against might feel reluctant to help realise the wider aims of diaspora. The proposal for reforms in citizenship and electoral law, for instance, will have greater possibility of succeeding if they are widely supported by all sections of the diaspora.

Moreover, neglecting the presence of migrant workers as important diasporic subjects hinders the advancement of their economic potential through remittances. At present, although remittances sent from migrant workers contribute significantly to Indonesia's economy, the Indonesian government has not effectively governed the process of remittance transfers. Foreign transfer providers make millions through transfer charges, reducing the benefit of remittances for both the migrant workers and for the country. Indonesia should work on developing an inclusive diaspora engagement strategy to address this problem and fully realise the economic benefits of its migrants abroad.

Attempts to reduce the division between 'white-collar' diaspora members and migrant manual workers have taken place. One example is the formation of a special taskforce for migrant workers' protection in IDN. Such initiatives stress the contribution of diaspora to help protect other migrant categories vulnerable to exploitation. However, there is also a propensity to use nationalist and solidarist narratives to claim unity and solidarity among diaspora to promote causes such as dual citizenship and a special electorate for the diaspora. A number of critics have 
questioned whether this strategy serves the interest of all migrants or only particular groups. While some sections of the diaspora may be able to increase their leverage and actively seek greater political participation at home, migrant workers' political aspirations may not be fully facilitated and accommodated.

While transnational spaces have opened up avenues where diasporic communities can significantly contribute to the economy of their homeland, these spaces are also sites of inequality. For this reason, if Indonesia wants to build a successful diaspora engagement strategy, it needs to work on inclusiveness and equality among its diasporic communities.

Authors: Annisa D. Amalia, Muhamad Arif, Arivia T.D Yuliestiana

This article was written by authors as a part of a research project on Indonesian Diaspora Politics funded by Indonesia Endowment Fund for Education (LPDP) and Research and Innovation Agency (BRIN), conducted by a group of six researchers from the Department of International Relations Universitas Indonesia: Dr Ani W. Soetjipto, Dr Dwi A. Soendrijo, Avyanthi Azis, Annisa D. Amalia, Muhamad Arif, and Arivia T. D. Yuliestiana.

Image: Indonesian migrants workers in Malaysia. Credit: UN Women/Flickr. 